\title{
SURVEILLANCE OF AVIAN INFLUENZA IN FAECAL SAMPLES OF WILD BIRDS AT SAURAHA, CHITWAN NATIONAL PARK
}

\author{
Md. Hus. Azad ${ }^{1 *}$, P. Manandhar ${ }^{2}$ and D. Sedai ${ }^{2}$ \\ ${ }^{1}$ Animal Nutrition Division, Khumaltar, Lalitpur \\ ${ }^{2}$ Central Veterinary Laboratory, Tripureshwor \\ ("email: azardhusneid@hotmail.com)
}

\begin{abstract}
Wild birds are the carrier of Avian influenza virus as reservoir. They spread virus through faecal drops. Considering this fact, a study was carried out to detect the avian influenza virus in fresh fecal swabs in Chitwan National Park, Sauraha. A total of 40 samples were collected from Baghmara Buffer zone community forest,30 samples from Rapti river bank and 10 samples from National trust for nature conservation areas. The faecal samples were collected during the summer season (March). The test was carried out by using a rapid test kit (synbiotic kit) USA. On rapid test, all the 80 samples were negative. All 80 samples were further inoculated in nine days embryonated eggs for haemagglutination tests for the confirmative diagnosis that showed negative result. Preliminary diagnosis revealed that wild birds were free from Avian Influenza in Chitwan National Park region.
\end{abstract}

Keywords: Avian Influenza, haemagglutination, wild birds

\section{INTRODUCTION}

Avian influenza is an infectious disease of fowls characterized by a variety of syndromes ranging from sub clinical to acute generalized fatal disease. Historically, outbreaks of avian influenza first occurred in Italy in 1878, when it was a lot of dead birds (Ligon, 2005). Then came another outbreak of Avian Influenza in Scotland in 1959 (Fauci, 2006). The virus that causes Avian Influenza in Italy and Scotland are the current strain of H5N1 virus appeared again attacked poultry and humans in various countries in Asia, including Indonesia, which caused many deaths in humans (Sims, 2006). Avian influenza refers to the disease caused by infection with Type A influenza viruses. It was first identified in Italy in the early 1900s and is now known to exist worldwide. These viruses occur naturally and have been isolated from more than 100 different species of wild aquatic birds which act as reservoir. It can infect domestic poultry and other bird and animal species (Hanson et al., 2005). Influenza pandemics are associated with high morbidity, excess mortality, and social and economic disruption. Avian influenza virus can be divided into two groups, highly pathogenic avian influenza virus (HPAI) and low pathogenic avian influenza virus (LPAI) based on their difference in virulence. Infection of poultry with HPAI viruses can cause severe disease with high mortality. Both HPAI and LPAI viruses can spread rapidly through poultry flocks (Rebel et al., 2011). Avian influenza refers to infection of birds with avian influenza Type A viruses. These viruses occur naturally among wild aquatic birds worldwide and can infect domestic poultry and other bird and animal species. Wild aquatic birds can be infected with avian influenza A 
viruses in their intestines and respiratory tract, but usually do not get sick. However, avian influenza A viruses are very contagious among birds and some of these viruses can sicken and even kill certain domesticated bird species including chickens, ducks, and turkeys (Obenaeur et al., 2006). It should also be realized that our knowledge of LPAI viruses in wild birds cannot simply be extrapolated to HPAI viruses. For instance, the most important host species may be quite different (Ellis et al. 2004; Liu et al; 2005).

On 9 January 2017, the National Health and Family Planning Commission of China reported to WHO 106 cases of H7N9 which occurred from late November through late December, including 35 deaths, 2 potential cases of human-to-human transmission, and 80 of these 106 persons stating that they have visited live poultry markets. The cases are reported from Jiangsu (52), Zhejiang (21), Anhui (14), Guangdong (14), Shanghai (2), Fujian (2) and Hunan (1). Similar sudden increases in the number of human cases of H7N9 have occurred in previous years during December and January (WHO, 2017).

AIVs replicate in the gastrointestinal tract (sampled by swabbing the cloaca or collecting droppings) and in the respiratory tract (sampled by swabbing the oropharynx). Individual mallards (Anas platyrhynchos) have historically shown higher detection probability from cloacal swabs. Accordingly, $61 \%$ of studies investigating contemporary infection sampled the gastrointestinal tract alone. However, the site of infection may differ between species (Brown et al., 2008).

\section{MATERIALS AND METHODS}

\section{Study area}

The samples were collected from the Chitwan National Park, Sauraha. Wild birds are seasonal migratory, and study has revealed that most of the wild bird species were found in Chitwan National Park. The samples were collected from Baghmara buffer zone community forest, Rapti river bank and National trust for nature conservation areas at the periphery of Chitwan national park.

\section{Sample collection}

The fecal swabs were collected from the birds from the green leaves of bushes and plants and transported to the media containing Transport medium with penicillin $2000 \mathrm{IU} / \mathrm{ml}$, streptomycin $2 \mathrm{mg} / \mathrm{ml}$, gentamycin $50 \mathrm{ug} / \mathrm{ml}$. Then samples were stored at cool box containing ice packs. The samples were collected in morning and evening period of the days because this is the time that birds excret faeces. A total of 80 samples were collected for the study from the wild birds of Chitwan National Park. Out of them 40 samples were collected from Bhagmara Bufferzone Community forest, 30 from Rapti River Bank and 10 from National trust for Nature Conservation.

\section{Preparation of Phosphate buffer saline (PBS)}

The following ingredients were used for the preparation of PBS solution (Table 1). The ingredients were dispensed in a beaker and the solution was mixed well. It was filtered through a muslin cloth. The $\mathrm{pH}$ was adjusted by adding $\mathrm{HCl}$ or bicarbonates drop by drop with the pipette and finally autoclaved at $121^{\circ} \mathrm{c}$ for 15 minutes. 
Table 1: Phosphate buffer solution

\begin{tabular}{ll}
\hline Ingredients & Gram/litre \\
\hline Sodium chloride(NaCl) & $8 \mathrm{~g}$ \\
Di-sodium hydrogen orthophosphate $\left(\mathrm{Na}_{2} \mathrm{HPO}_{4}\right)$ & $1.15 \mathrm{~g}$ \\
Potassium chloride(KCl) & $0.2 \mathrm{~g}$ \\
Distilled water & $1 \mathrm{litre}$ \\
\hline
\end{tabular}

\section{Preparation of Alsever's solution}

The following ingredients were used for the preparation of Alsevier's solution (Table 2). The ingredients were dispensed into a beaker to mix well. The beaker was covered with aluminium paper and finally autoclaved at $121^{\circ} \mathrm{c}$ for 15 minutes at 15 pounds of pressure.

Table 2: Alsevier's solution

\begin{tabular}{ll}
\hline Ingredients & Gram/litre \\
\hline Dextrose & $20.5 \mathrm{~g}$ \\
Sodium citrate & $8 \mathrm{~g}$ \\
Citric acid & $0.55 \mathrm{~g}$ \\
Sodium chloride & $4.2 \mathrm{~g}$ \\
Distilled water & $100 \mathrm{ml}$ \\
\hline
\end{tabular}

\section{Rapid test}

The collected samples were transported in a cool box to Central Veterinary Laboratory, Tripureshwor. The samples were centrifuged for 15 minutes to obtain supernatant. Then, initial screening test was performed using rapid test kit for avian influenza virus (Synbiotics from the USA). The flu detect strip is an in-vitro, rapid immune chromatographic assay designed to aid in the qualitative detection of Influenza Type A virus in tracheal and clocal specimen from symptomatic birds or flocks. This assay detects all 15 subtypes of Influenza type a virus. First $200 \mu 1$ of the viral transport media containing extracted sample was transferred into the test tube provided and 3 drops of extraction buffer was added to the tube. The test strip was removed from the descant vial for each sample to be tested. Then the strip was placed directly into the test tube containing the sample. The test strip was placed so that the pink pad was submerged in the extracted sample. The test tube was inoculated in the sample for 15 minutes then test strip was removed from the test tube to read. After 15 minutes, pink/purple bands in the Centre of the test strip between the two absorptions pads would be observed in positive cases. The samples were negative on rapid test However; inoculation of samples in chickens' eggs was carried out for confirmatory diagnosis.

\section{Inoculation of samples in chicken embroyonated eggs}

The inoculation of the sample was carried out in 9-day old embroyonated hen eggs. For each sample $0.02 \mathrm{ml}$ of the samples were inoculated through allantoic sac route of at least 
four embryonated eggs. The eggs were incubated at $35-37^{\circ} \mathrm{c}$ for 72 hours. Eggs containing dead or dying embryos as they arose, and all eggs remaining at the end of the incubation period, were chilled at $4^{\circ} \mathrm{c}$ and the allantoic fluids was harvested from each egg. Then they were tested for haemagluttination (HA) activity. Detection of HA activity indicates a high probability of the presence of an influenza type A virus. The fluid giving negative reactions that were passed into another batch of eggs.

\section{Haemagglutination (HA) Test}

The reagents used for these tests are isotonic PBS $(0.1 \mathrm{~m})$, PH 7.0-7.2 and red blood cells taken from a minimum of three SPF chickens and pooled in an equal volume of Alsever's solution. Cells were washed three times in PBS before using as a $1 \%$ (packed cell v/v suspension). 50ul of PBS was dispensed into each well of plastic U-bottomed microtitre plate. $50 \mu 1$ of sample suspension (i.e allantoic fluid) was poured in the first well followed by serial dilution of the sample suspension that was made across the plate. $50 \mu 1$ of $1 \%$ (V/V) chicken RBCs was added to each well. The plate was gently tapped to mix and then RBCs were allowed to settle, and plate was determined at $37^{\circ} \mathrm{c}$ or at room temperature $27^{\circ} \mathrm{c}$ for 40 minutes. HA was determined by tilting the plate and observing the presence or absence of tear-shaped streaming of RBCs. The titration was read to the highest dilution giving complete HA. The fecal samples for HA tests were negative.

\section{Haemagglutination Inhibition (HI) Test}

$25 \mu 1$ PBS was dispensed into each well of plastic U-bottomed microtiter plate. $25 \mu 1$ serum in the first well followed by the serial dilution of the serum. Again, 25 ul diluted sample in each well (i.e one to twelve) on the respective labeled to keep single sample in one line. Then incubation was done for 45 minutes. Then 25 ul of $1 \%$ chicken RBCs was added in all the wells. Then the wells were incubated at $4^{\circ} \mathrm{c}$ for 45 minutes. Finally, result was observed. (In positive case, there would be appearance of distinct button or tear shaped but in negative case there would be no appearance of distinct button, however there was agglutination of RBCs. The fecal samples for HI tests were negative.

\section{Data Analysis}

Datas of faecal samples collected from the Chitwan National Park were analyzed by Oneway Anova test for every measurement using statistical package Minitab 2000, versions 13.20 (Minitab,2000).

\section{RESULTS}

The samples were collected from Bhaghmara Buffer zone community forest, Rapti river Bank and National trust for nature conservation during the period of march to august 2007 as mentioned in below tables.

Total forty samples of wild birds (Blackbish, Oriental Mag Pierobin, Black hooded orial, Asian open billstork, Jungle babler, Common tailor bird, Eurasian golden orial, Large cuckooshire birds) were collected from Bhaghamara Buffer zone community forest (Table3). The faecal drops were collected at morning and evening from nine different 
varieties of wild birds. The samples results were negative on Rapid and Haemagglutination test.

Table 3: Site of sample collection and result of Rapid test and HA

\begin{tabular}{|c|c|c|c|c|}
\hline $\begin{array}{l}\text { Site of sample } \\
\text { collection }\end{array}$ & $\begin{array}{l}\text { Sample } \\
\text { size }\end{array}$ & Types of birds & $\begin{array}{l}\text { Number of } \\
\text { samples in each } \\
\text { test tube }\end{array}$ & $\begin{array}{l}\text { Results of } \\
\text { Rapid and HA } \\
\text { test }\end{array}$ \\
\hline \multirow{9}{*}{$\begin{array}{l}\text { Baghmara } \\
\text { Buffer Zone } \\
\text { Community } \\
\text { Forest }\end{array}$} & \multirow{9}{*}{40} & Blackbish & 7 & Negative \\
\hline & & Oriental Mag pierobin & 6 & Negative \\
\hline & & Rufous Treepie & 5 & Negative \\
\hline & & Black hooded orial & 7 & Negative \\
\hline & & Asian open billstork & 8 & Negative \\
\hline & & Jungle babler & 2 & Negative \\
\hline & & Common tailor bird & 3 & Negative \\
\hline & & Eurasian golden orial & 1 & Negative \\
\hline & & Large cuckooshire & 1 & Negative \\
\hline
\end{tabular}

Table 4: Site of sample collection and result of Rapid test and HA

\begin{tabular}{lllll}
\hline $\begin{array}{l}\text { Site of sample } \\
\text { collection }\end{array}$ & $\begin{array}{l}\text { Sample } \\
\text { size }\end{array}$ & Types of birds & $\begin{array}{l}\text { Number of samples } \\
\text { in each test tube }\end{array}$ & $\begin{array}{l}\text { Results of Rapid } \\
\text { and HA test }\end{array}$ \\
\hline $\begin{array}{l}\text { Rapti } \\
\text { Bank }\end{array}$ & River 30 & $\begin{array}{l}\text { Lesser adjunt stork } \\
\text { Chestnut tailed }\end{array}$ & 6 & $\begin{array}{l}\text { Negative } \\
\text { Negative }\end{array}$ \\
& & & \\
& starling & Asian open billstork & 7 & Negative \\
& & Pound heron & 3 & Negative \\
& & Spangled drongo & 6 & Negative \\
& Indian roller & 4 & Negative \\
\hline
\end{tabular}

Total thirty samples of wild birds (Lesser adjunt stork, Chestnut tailed starling, Asian open billstork, Pound geron, Spangled drongo, Indian roller) were collected from Rapti river Bank (Table 4). The faecal drops were collected at morning from six different varieties of wild birds. The samples results were negative on Rapid and Haemagglutination test.

Total ten samples collected of wild birds (long tailed shrike, grey crown wood pecker, Red vented bull bull, Black dronge, Indian cuckoo, wild pigeon, crow) from National Trust for nature conservation areas. The faecal drops were collected at morning from seven different varieties of wild birds. 
Nepalese Vet J. 34: 18-25

Table 5: Site of sample collection and result of Rapid test and HA

\begin{tabular}{|c|c|c|c|}
\hline $\begin{array}{lll}\text { Site of } & \text { sample } & \text { Sample } \\
\text { collection } & & \text { size }\end{array}$ & Types of birds & $\begin{array}{l}\text { Number } \\
\text { samples in each } \\
\text { test tube }\end{array}$ & $\begin{array}{l}\text { Results of } \\
\text { Rapid and HA } \\
\text { test }\end{array}$ \\
\hline \multirow[t]{7}{*}{$\begin{array}{l}\text { National Trust for } 10 \\
\text { nature conservation }\end{array}$} & $\begin{array}{l}\text { Long tailed } \\
\text { shrike }\end{array}$ & 1 & Negative \\
\hline & $\begin{array}{l}\text { Grey crown } \\
\text { woodpecker }\end{array}$ & 2 & Negative \\
\hline & $\begin{array}{l}\text { Red vented } \\
\text { bullbull }\end{array}$ & 1 & Negative \\
\hline & Black dronge & 1 & Negative \\
\hline & Indian cuckoo & 3 & Negative \\
\hline & Wild pigeon & 1 & Negative \\
\hline & Crow & 1 & \\
\hline
\end{tabular}

\section{DISCUSSION}

The total numbers of samples were negative in rapid and Haemagglutination test. In the surveillance of wild birds in Europe, only one percent of sample found to be positive in a sample of 8500 taken in a period of two years. Winker et al. (2007) reported isolation of 22 avian influenza from a sample of 1700 from 1100 migratory birds in the state of Alaska, USA. So, in comparison to these samples our samples were very small and collected within a period of a week. Virus remains infectious for 24 hours to 48 hours on nonporous environmental surfaces and less than 12 hours on porous surfaces according to the report of (ISDA,2006). So, the samples might have given negative results. Samples might have been confused with the fresh samples due to dew in the morning. Idaho state departmentof Agriculture (2006) report suggests that acidic $\mathrm{pH}$ conditions inactivate the virus. So, the samples that were collected from the river banks might cause the virus inactive.

The prevalence of AIV infection has long been recognized to vary over time and space. Viruses have been most frequently isolated from duck populations in North America and europe in late summer and early autumn (Suss et al., 1994). Less frequent isolations from wintering populations have prompted suggestions that prevalence rapidly decreases over the course of autumn migration.so, pre-migratory staging grounds in late summer and early autumn are considered the optimal time and location for conducting surveillance among waterfowl (Brown et al., 2008). This research supports the season of our sample collection too. Despite sampling $>56,000$ birds in the Netherlands from 1998 to 2009, only 20 of the 174 species were sampled $>300$ times. Moreover, prevalence in each species may vary over space and time. Although passerines have often been found negative for Avian infection, recent evidence suggests that, when sampled in or near waterfowl-rich bodies of water, a high proportion of individuals from 8 different passerine families show infection (Peterson et al.,2008). The above research gives strong evidence that the large 
number of samples are required for the surveillance of such type of researches. The samples were collected during the period of the summer so due to high temperature virus might be inactivated so due to this the results might have been negative. However, for proper risk assessment studies, we need better understanding of the interface between wild and domestic birds, the possible transmission of influenza viruses between these populations, bird behavior, age, structures of populations, and detailed migration routes.

\section{CONCLUSION}

The fecal swabs samples collected from the wild birds were negative on both rapid and haemagglutination test. Similarly (Adhikari et al., 2006) had also carried surveillance of Avian influenza in Chitwan National park and Zoo, Jawlakhel. It was reported that collected faecal swabs were negative on HA test. The surveillance of wild birds to be performed both in summer and winter seasons. A regular active surveillance programme is essential in wild birds as many of them are acting as the reservoir of the avian influenza. The regular survelliance programme could be carried in other national parks too. These types of surveillance indicate warning signals for the introduction of HPAI, H5N1 virus and provide access to strains for characterization. However, for proper risk assessment studies, we need better understanding of the interface between wild and domestic birds, the possible transmission of influenza virus between these populations, bird behavior, age structures of populations, and detailed migration routes. The current increased interest in influenza virus surveillance in wild and domestic birds provides a unique opportunity to increase our understanding not only of HPAI epidemiology but also of ecology of Low pathogenic avian influenza viruses in their natural hosts, at the same time and cost.

\section{ACKNOWLEDGEMENT}

I would like to express my sincere gratitude to the Internship Advisory committee, Dr. Binayak P. Rajbhandari, Dr. Subarna Lal Shrestha. I am heartly thankful to Dr. Shankhar Pandey for providing me informations, refrences, suggestions and support during the period of study. My heartfelt thanks go to Mr. Manoj Chaudhary, Wild bird specialist for providing me the sites and samples collection required for this study.

\section{REFERENCES}

Adhikari, S. (2006).Minithesis. Survelliance of Avian influenza in wild birds of Nepal.

Brown, J.D. and Stallknecht, D.E. (2008). Wild bird surveillance for the avian influenza virus. In: Spackman E, editor. Methods in molecular biology.Totowa (NJ): Humana Press. pp. 85-97.

Hanson, B.A., Stallknecht, D.E., Swayne D.E., Lewis, L.A. and Senne, D.E. (2005). Avian influenza viruses in Minnesota dicks. Avian Dis.47: pp:867-71.

Idaho state department of Agriculture. (2006). Evolution of highly pathogenic avian influenza type $\mathrm{H} 5 \mathrm{~N} 1$ in Europe. Review of disease ecology, trends and perspectives of spread autumn-winter.2006. 
Ellis, T., Lau, L.T and Collins, R.A. (2004).Detection of highly pathogenic and low pathogenic avian influenza subtype H5 (Eurassian lineage) using NASBA.J. VIROL.pp213-225.

Fauci, A.S. (2006). Emerging and Re-Emerging Infectious Diseases: Influenza as a Prototype of the Host-Pathogen Balancing Act. Elsevier Cell. pp. 665 -670.

Ligon, B.L. 2005. Avian Influenza Virus H5N1: A Review of Its History and Information Regarding Its Potential to Cause the Next Pandemic. Seminars in Pediatric Infectious Diseases, Elsevier, pp. 326 - 335.

Obenaur, Fouchier R.A., Olsen B., Bestebroer T.M., Herfst S., Van der kemp L. and Rimmelzwaan G.F. (2006). Influenza A virus surveillance in wild birds in northern Europe. Avian Did.pp:857-60.

Liu, G.W. (2005). Genesis of a highly pathogenic and potentially pandemic H5N1 influenza virus in eastern Asia.Natuire.pp:209-13.

Minitab. (2000). Minitab Statistical software, release 1320.Minitab Inc., State college. PA. USA.

Peterson, A.T., Bush, S.E., Spackman, E., Swayne D.E. and I.P.H.S. (2008). Influenza A virus infections in land birds, People's Republic of China. Emerg Infect Dis.14: 1644-1646

Rebel, J.M., Peeters, B., Fijten, H., Post, J., Cornelissen, J., Vervelde, L. (2011). Highly pathogenic or low pathogenic avian influenza virus subtype H7N1 infection in chicken lungs: small differences in general acute responses. Veterinary Research. 42 (1): 10.

Sims,L.D., J. Domenech., C. Benigno., S. Kahn., A. Kamata., J. Lubrouth., V. Martin and P. Roeder. (2006). Origin and evolution of highly pathogenic H5N1 avian influenza in Asia. The Veterinary Record, pp. $159-164$.

Suss, J., Schafer, J., Sinnecker, H., Webster, R.G. (1994). Influenza virus subtypes in aquatic birds of eastern Germany. Arch Virol.135: 101-114.

Winker, K., K.G. McCracken and D.D. Gibson. (2007). Movements of Birds and Avian Influenza from Asia into Alaska. Emerging Infectious Diseases. 13(4):547-552.

WHO (2017) Human infection with avian influenza A (H7N9) virus - China, WHO, Disease outbreak news, 17 January 2017. 